\title{
THE RELATIONSHIP BETWEEN WELLBEING DIMENSIONS AND GDP: A REGIONAL EMPIRICAL STUDY
}

\author{
Dorina LAZAR ${ }^{\mathrm{a} *}$ \\ ${ }^{a}$ Babes-Bolyai University, Faculty of Economics and Business Administration, \\ Cluj-Napoca, Romania
}

Please cite this article as:

Article History:

Lazar, D., 2021. The relationship between wellbeing

Received: 27 May 2021

dimensions and GDP: a regional empirical study. Accepted: 12 September 2021 Review of Economic Studies and Research Virgil Madgearu, 14(2), pp.45-57.

doi: 10.24193/RVM.2021.14.79.

Abstract: In this paper are considered a large number of indicators for measuring wellbeing at the Romanian counties level. The paper attempts to add the following contributions: a) analyses the shape of the distribution of wellbeing indicators using the kernel density estimation $b$ ) uses the factor analysis to identify the wellbeing dimensions that GDP well represents and quantify to what extent. Results show persistent disparities in time, with a few exceptions. It is worth mentioning that, for economic indicators, there is a small group of counties leading ahead of the rest of the country. A part of wellbeing information is captured by GDP, namely the wage, access to utilities, jobs, housing, and health dimensions, but the GDP does not incorporate at least the information related to education, environment, and security.

Key words: wellbeing indicators; GDP; counties; Kernel density; factor analysis JEL Classification: B55; I31; C19

(C) 2021 Alma Mater Publishing House. All rights reserved.

* Corresponding author. E-mail address: dorina.lazar@econ.ubbcluj.ro. 
Review of Economic Studies and Research Virgil Madgearu, 2021, 14(2)

\section{References:}

1. Barrington-Leigh, C. and Escande, A., 2018. Measuring progress and wellbeing: A comparative review of indicators. Social Indicators Research, 135(3) pp.893-925. https://doi.org/10.1007/s11205-016-1505-0.

2. Benedek, J. and Lembcke, A.C., 2017. Characteristics of recovery and resilience in the Romanian regions. Eastern Journal of European Studies, 8(2), pp.95-126.

3. Bleys, B., 2012. Beyond GDP: Classifying alternative measures for progress. Social Indicators Research, 109 (3), pp 355-376.

4. Goschin, Z., 2015. Territorial inequalities and economic growth in Romania.A multi-factor approach. Procedia Economics and Finance, 22, pp.690-698. https://doi.org/10.1016/S2212-5671(15)00285-3.

5. Goschin, Z., 2017. Exploring regional economic convergence in Romania. A spatial modeling approach. Eastern Journal of European Studies, 8(2), pp.127-146.

6. Ivan, K., Holobâcă, I.H., Benedek, J. and Török, I., 2020. Potential of Night-Time Lights to Measure Regional Inequality. Remote Sensing, 12(1), 33. https://doi.org/10.3390/rs12010033.

7. Jones, C.I. and Klenow P.J., 2016. Beyond GDP? Welfare across countries and time. American Economic Review, 106(9), pp.2426-57. https://doi.org/10.1257/aer.20110236.

8. Mazziotta, M. and Pareto, A., 2019. Use and misuse of PCA for measuring wellbeing. Social Indicators Research, 142(2), pp.451-476. https://doi.org/10.1007/s11205-018-1933-0.

9. Magrini, S., 2009. Why should we analyse convergence using the distribution dynamics approach? Scienze Regionali, 8(1), pp.5-34. https://doi.org/10.3280/SCRE2009-001001.

10. OECD, 2014. How's Life in Your Region? Measuring Regional and Local Wellbeing for Policy Making. OECD Publishing, <https://doi. org/10.1787/9789264217416-en>, [Accessed 15 May 2021].

11. Otil, M.D., Miculescu, A. and Cismas, L.M., 2015. Disparities in regional economic development in Romania. Scientific Annals of the "Alexandru Ioan Cuza", University of Iaşi Economic Sciences, 62, pp.37-51. https://doi.org/10.1515/aicue-2015-0035.

12. Peiro-Palomino, J., 2016. European regional convergence revisited: the role of intangible assets. The Annals of Regional Science, 57(1), pp.165-194. https://doi.org/10.1007/s00168-016-0767-4. 
LaZAR, The Relationship Between WeLlbeing Dimensions AND GDP...

13. Peiró-Palomino, J., 2019. Regional wellbeing in the OECD. The Journal of Economic Inequality, 17(2), pp.195-218. https://doi. org/10.1007/s10888-018-9398-6.

14. Royuela, V. and García, G.A., 2015. Economic and social convergence in Colombia. Regional Studies, 49(2), pp.219-239. https://doi.org/1 $0.1080 / 00343404.2012 .762086$.

15. Stiglitz, J. E., Sen, A. and Fitoussi, J., 2009. Report by the Commission on the Measurement of Economic Performance and Social Progress. Technical Report. Commission on the Measurement of Economic Performance and Social Progress, Paris, <https://ec.europa.eu/ eurostat/documents/8131721/8131772/Stiglitz-Sen-FitoussiCommission-report.pdf $>$, [Accessed 5 May 2021].

16. Zaman, G. and Goschin, Z., 2014. Economic Crisis and Wage Divergence: Empirical Evidence from Romania. Prague Economic Papers, 4, pp.493-513. https://doi.org/10.18267/j.pep.495. 